\title{
Ethics and ESG
}

Anona Armstrong1

\begin{abstract}
This paper provides theories, models and practices to assist in understanding ethical decision making in relation to environmental, social and governance issues. It begins by defining sustainability and how it is measured and reported. The most influential is the UN's definition of sustainability and its measurement by compliance with its 17 Sustainability goals. In his recent report into the finance sector, the Royal Commissioner was scathing in his assessment of the lack of integrity, honesty and ethics and endorsed the importance of reporting non-financial indicators of performance. However, there are few explanations of the links in the literature between ethics and ESG and how ethical decisions could be managed. The purpose of this paper is to address this issue by exploring the questions: What are: ethics? Business ethics? The main ethical theories? What is the relationship between ESG and ethics? What is the difference between ethics and morals? How do we apply ethical reasoning to ESG?
\end{abstract}

\section{JEL classification: L21}

Keywords: Sustainability, Ethics, Ethical reasoning

\footnotetext{
${ }^{1}$ Victoria University Business School PO Box 14428

Melbourne, VIC 8001, Victoria, Australia

Email anona.armstrong@vu.edu.au
} 


\section{Introduction}

Sustainability refers to development that meets the needs of the present without compromising the ability of future generations to meet their own needs. Business sustainability is often defined as managing the triple bottom line, a process by which companies manage their financial, social and environmental risks (Armstrong and Sweeney 2002; Armstrong et al. 2001). Interest in sustainability grew in the mid- $20^{\text {th }}$ century driven by increased global awareness of the threat posed by climate change and the human-induced enhanced greenhouse effect produced largely by forest clearing and the burning of fossil fuels. In September 2015, the General Assembly of the United Nations adopted the 2030 Agenda for Sustainable Development that aimed to achieve 169 targets to meet 17 Sustainable Development Goals (SDGs).

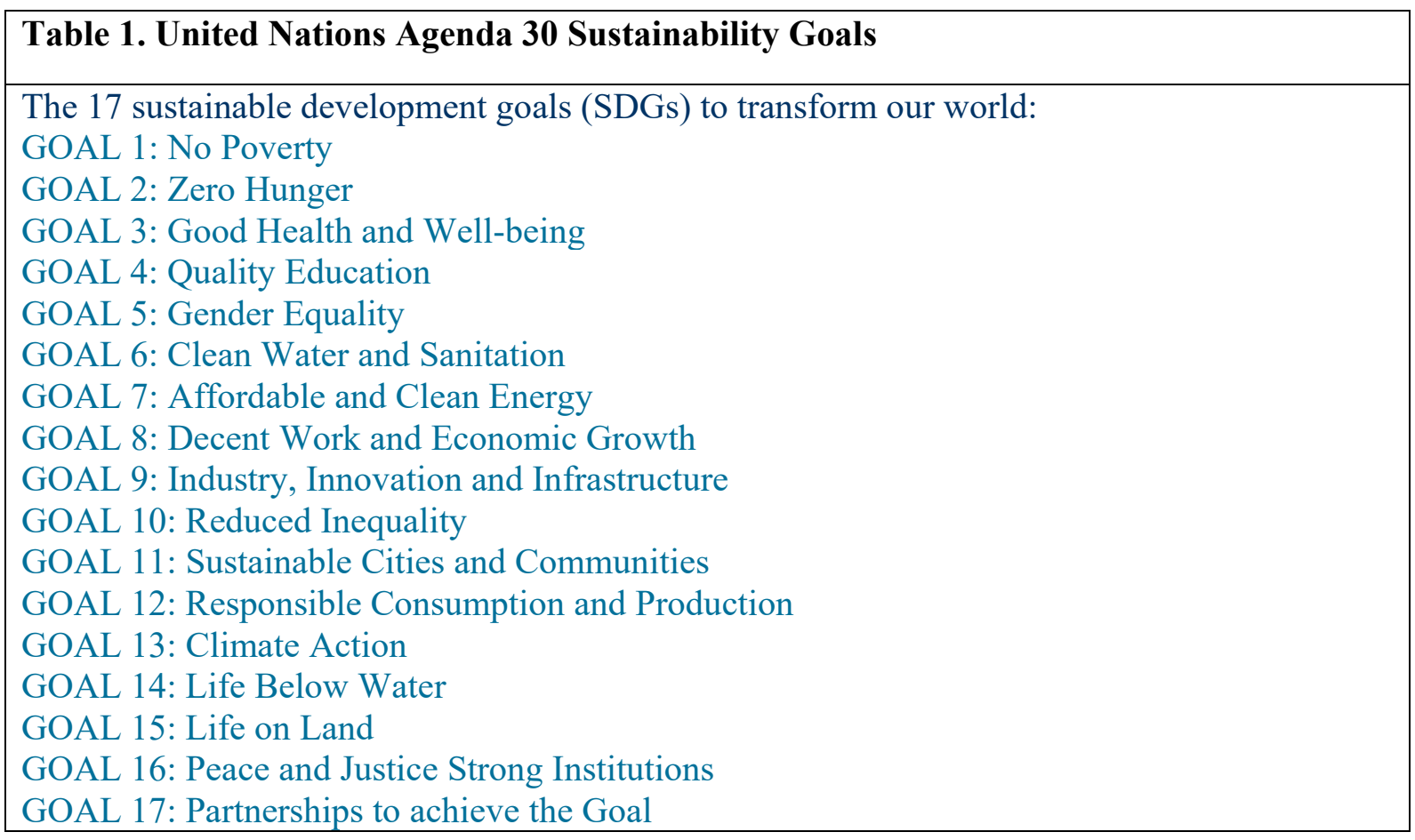

Several global indices have been designed to measure and report sustainability performance. Sustainability reporting is the practice of measuring, disclosing, and being accountable to internal and external stakeholders for organizational performance towards the goal of sustainable development (Heenetigala et al 2016). Integrated reporting takes the concept a step further and encourages companies to integrate their financial, economic and social performance reporting into one integrated balance sheet.

The Global Reporting Initiative (GRI), the UN Global Compact and the World Business Council for Sustainable Development (WBCSD), developed the SDG Compass to help businesses understand and measure their contribution to the SDG goals. The SDG Compass lists over 1500 indices that could be used to measure different aspects of sustainability. The GRI is an international independent organization focussed on reporting the impact of business on critical sustainability issues such as climate change, human rights, corruption and many other issues. GRI Standards are developed and approved by the Global Sustainability Standards 
Board (GSSB) which has sole responsibility for setting GRI Standards. They are aligned with international declarations such as the United Nations Guiding Principles on Business and Human Rights, the ILO Conventions, the UN Global Compact Ten Principles, and the OECD Guidelines for Multinational Enterprises. GRI claims that the GRI sustainability indices are used by $93 \%$ of the world's largest 250 corporations to report on their sustainability performance" (GRI, 2015).

Environmental, social and governance (ESG) measures describe the environmental, social and governance issues that are considered to influence corporate behaviour in their investment decisions (IFAC, 2012). The environment refers to the awareness of climate change, population growth, and their detrimental impact on the natural environment. The term "Social" encompasses corporate social responsibility (CSR). CSR is the response to issues such as climate change and population growth, and the impact of corporate activities on the communities in which they operate.

By the time of the Cadbury Report (Cadbury 1992), poor corporate governance began to emerge as a deciding factor in the collapse of several companies in the financial sector. Corporate governance has several definitions depending on the context in which it is implemented. It is essentially about the leadership of a company, that is, the role of a board of directors in directing and controlling a company. External governance mechanisms refer to those factors impacting on a company but beyond the direct control of the board of directors, e.g. legislation and regulations, and actions of various stakeholders. Internal governance mechanisms are the structures and processes intended to ensure board independence and accountability through reporting and transparent disclosure, managing risk and avoiding corruption and bribery. They include the structure of a board and its committees, their independence, and the systems of reporting and accountability to the board. Examples of governance issues include: executive benefits and compensation, bribery and corruption, shareholder rights, business ethics, board diversity, board structure, independent directors, risk management, whistle-blowing schemes, stakeholder dialogue, lobbying, and disclosure.

Table 2. Measures of ESG Performance

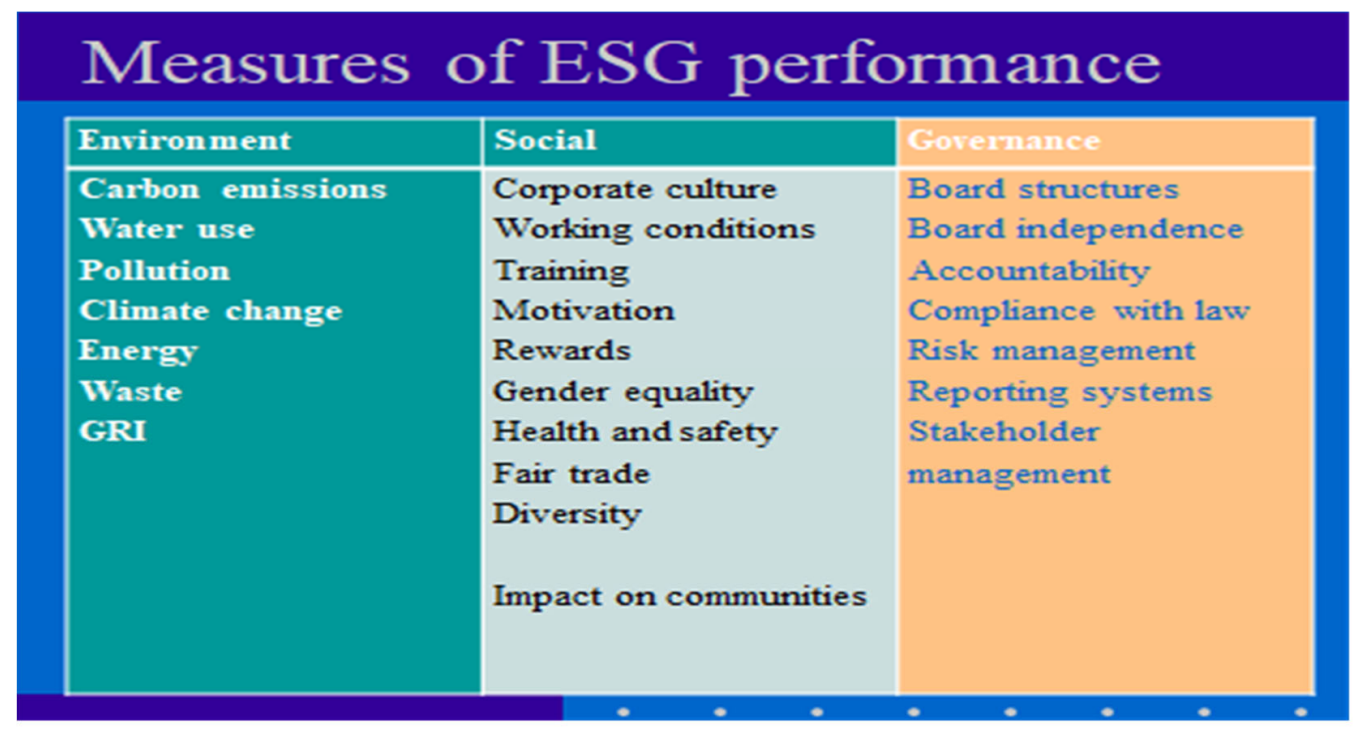


In Australia, the Royal Commissioner investigating the Royal Commission into the Financial Sector (2019) identified poor governance as a major cause of the disgraceful ways in which customers had been cheated by their banks. In his Report, the Royal Commissioner was scathing in his assessment of the lack of integrity, honesty and ethics and endorsed the importance of reporting non-financial indicators of performance. However, there are few explanations of the links between ethics and ESG. The purpose of this paper is to address this issue by exploring the questions:

- What are: ethics? Business ethics? The main ethical theories?

- What is the relationship between ESG and ethics?

- What is the difference between ethics and morals?

- How do we apply ethical reasoning to ESG?

\section{What is meant by ethics?}

Ethical principles guide the actions and practices that are directed at improving the welfare of society. Ethics determines what is good or right, what goals people and society ought to pursue, and what actions they ought to perform. The study of ethics represents a systematic attempt, through the use of reason, to question the rules that should govern human conduct and the values worth pursuing. The concerns with what is good for society and what actions are considered proper overlap issues with social mores and morals.

Business ethics addresses how personal moral norms apply to the activities and goals of commercial enterprises. Business ethics is not a separate moral standard, but the study of how the business context poses its own unique problems for the moral person who acts as an agent of this system. It is primarily concerned with clarifying the moral obligations and social responsibilities of the leaders who make business decisions (Buchholz, 1995, p.472) and attempts, to explain how personal moral norms apply to the activities and goals of commercial enterprises. This is not a separate moral standard, but the study of how the business context poses its own unique problems for the moral person who acts as an agent of this system. In many cases, business ethics requires the reasoning and judgement based on both principles and beliefs for making choices that balance economic self-interests against social and welfare claims.

\section{A distinction between ethics and morals: Everything's got a moral, if only you can find it (Lewis Carrol 1832-1898)}

An ethical decision is one in which somebody's welfare is at stake and in which somebody will be positively or negatively affected by the decision. In this case, justice and rights are considerations. Questions of justice and rights require decisions such as: When does a Board decide to recall a product with a defect knowing that it may put them out of business? At what stage should expenditure on environmental safety be increased? A job is advertised. Do you employ a female with higher qualifications than your friend (relative) who will, in any case, do an excellent job? At what stage do you tell employees that the company is closing down and they will be out of a job? People are begging for any job. Do you pay them less than the standard rates of pay? 
A moral decision concerns the right conduct, i.e. it relates to social manners or customs: holding the door open for a visitor; giving up a seat in a tram to an older person; helping someone pick up papers they may have dropped. The relationship between ethics and ESG is illustrated in Table 3. Issues that raise questions for leaders and individuals, emerge in relation to each of the environment, social and governance categories that require ethical decision making in order to arrive at an ethical response.

Table 3. ESG and Ethics

\begin{tabular}{|l|l|}
\hline ESG issues & Ethical questions \\
\hline Environment & $\begin{array}{l}\text { How do we respond to climate change } \\
\text { How do we manage waste? } \\
\text { How do we manage water? }\end{array}$ \\
\hline Social & $\begin{array}{l}-\quad \text { How do we address poverty? } \\
\text { and they will be out of a job? } \\
\text { People are begging for any job. Do you pay them less than the } \\
\text { standard rates of pay? }\end{array}$ \\
\hline Governance & $\begin{array}{l}\text { Does the board report on its governance? } \\
\text { Does the board support an ethical culture? } \\
\text { (or values performance at any price?) } \\
\text { What behaviours are rewarded in the company? (dodgy deals with } \\
\text { customers? Bonuses for just doing the job?) } \\
\text { How do you deal with whistle-blowers: doing the 'right' thing but an } \\
\text { embarrassment to the business? }\end{array}$ \\
\hline
\end{tabular}

\section{Ethical reasoning}

Ethical reasoning is required in business for at least three major reasons:

1. Laws are insufficient to cover all aspect or "grey" areas of a problem.

2. Free-market and regulated-market theories do not effectively inform managers about the impact of decisions.

3. Ethical reasoning is necessary because complex moral problems require an intuitive or learned understanding and concern for fairness, justice, due process to people, groups and communities. 
Ethical decisions in business are difficult because they do not usually demand a Yes or No answer. They relate to complex issues that often have extended consequences for multiple stakeholders and the outcomes can often be mixed and different. They also have personal outcomes for the individuals making the decisions. A clash of personal values with the values espoused by their organisation can also lead to dissonance and stress.

In ethical business decisions, managers often confront decisions between facts and values. A full description of an ethical business decision, does not automatically give a just answer. Many interest groups use the same facts to argue their cases. The Gun lobby following the Tasmanian tragedy argued that if people have guns they will be safer. Others argue that the tragedy demonstrates the danger of weapons in the community.

\section{Ethical Theories}

There are both unacceptable and acceptable ethical theories. Unacceptable theories include Ethical Egoism (serving only personal interests) and Relativism. Ethical Relativism holds that what is right is culturally determined. However, what is right in one society may be wrong for another. Cultural relativists would hold that when in Rome do as the Romans do. This could be interpreted as: when employing people in underdeveloped countries there is no need to apply safety and health standards found in the parent company.

Acceptable theories include:

- Teleological theories: consequences

- utilitarianism

- Deontological theories: (how things are done) doing ones duty :

- Eternal Law

- Kant's universalism/categorical imperative

- Rights/Personal liberty

- Distributive justice

- Stakeholder theory (considering the rights and needs of various people affecting a company or impacted by a company).

Utilitarianism is the most prominent of the teleological theories of ethics. Sometimes called consequentialist theories, teleological theories hold that the moral worth of an action or practice is determined by its consequences. The "rightness" or "wrongness" of an action or practice is determined by the results that an action or practice produces, e.g. Implementing ESG because it will prevent climate change.

What makes an action right or wrong is the good or evil that is produced by the act, not the act itself. Thus, teleological theories do not hold that an act has intrinsic value in and of itself but that all acts and practices must be evaluated in terms of the good or bad consequences they produce." (Buchholtz, 1995).

Utilitarianism emerged as a moral philosophy in Britain about the same time as Kant's theory in Germany. Deontological theories address duty and moral obligation. Promises should 
be kept and debts paid. One's duty is to keep promises and to pay debts, not because of good or bad results of such actions.

Eternal law refers to acting in accordance with the demands of a religion. Kant's categorical imperative suggests that an action is morally right for a person in a certain situation if, and only if, the person's reason for carrying out that action is a reason that he or she would be willing to have every person act on, in any similar situation he/she would be willing to have every person act on, in any similar situation. Rights may be negative or positive. Negative rights prohibit others from acting in certain ways; protecting the individual from interference by others. Positive rights require others to ensure that an individual receives certain entitlements: to free speech, sustenance, education, etc.

In contrast to the libertarian belief in the individual's fundamental right to freedom John Rawls' argued that within any society there are several equal liberties and justice is the dominant right. Justice is often expressed in terms of fairness or what is deserved. A person has been treated justly when he or she has been given what is due or owed that person, what he or she deserves or can legitimately claim. The so-called formal principle of justice states that like cases should be treated alike-equals ought to be treated the same or unequals unequally. John Rawls' two basic rules or principles which all persons in our type of society would use as a fair method of choosing principles to resolve social conflicts are:

1. each person has equal right to the most extensive basic liberties compatible with similar liberties for all;

2. social and economic equalities are arranged so that they are both:

(a) attached to the greatest benefit of the least advantaged persons, and

(b) offices and positions open to all under conditions of fair equality and opportunity. 
Armstrong | Ethics and ESG

Table 4. Example of a Stakeholder Analysis

\begin{tabular}{|c|c|c|}
\hline Stakeholder & Role & Interests, values, expectations \\
\hline $\begin{array}{l}\text { Government } \\
\text { Minister Angus } \\
\text { Taylor }\end{array}$ & $\begin{array}{l}\text { Political stability } \\
\text { Consumer support }\end{array}$ & $\begin{array}{l}\text { Aims: reliability, affordability, } \\
\text { emissions reduction }\end{array}$ \\
\hline Regulators & $\begin{array}{l}\text { Australian Energy Regulator (AER) } \\
\text { Australian Energy Commission AEMC } \\
\text { Victorian Government: Essential } \\
\text { Services Commission (ESC) } \\
\text { Australian Competition and Consumer } \\
\text { Commission (ACCC) }\end{array}$ & $\begin{array}{l}\text { Australian Energy Regulator has } \\
5 \text { year contracts with renewable } \\
\text { energy regulators re } \\
\text { development, energy returns and } \\
\text { incentives. } \\
\text { More interconnection between } \\
\text { state markets }\end{array}$ \\
\hline Market Operator & $\begin{array}{l}\text { Australian Energy Market Operator } \\
\text { National Electricity Market operates an } \\
\text { interstate spot trading market }\end{array}$ & $\begin{array}{l}\text { Support for interconnectors } \\
\text { linking the states. }\end{array}$ \\
\hline Producers & Are regulated and taxed & \begin{tabular}{|l} 
Seek National Policy to provide: \\
- \\
Policy certainty and \\
stability; \\
- \\
Opportunities for future \\
investment; \\
- \\
Remove risk and \\
uncertainty. \\
\end{tabular} \\
\hline Retailers & $\begin{array}{l}\text { Energy Retailers Association of Australia } \\
\text { Australian Energy Council } \\
\text { Electricity Supply Association of } \\
\text { Australia }\end{array}$ & Sales and Profit \\
\hline Consumers & $\begin{array}{l}\text { Big Users and domestic } \\
\text { Consumer Action Law Centre } \\
\text { Consumer Action Working Group }\end{array}$ & $\begin{array}{l}\text { Affordability, } \\
\text { Reliability } \\
\text { Sustainability } \\
\text { Emissions reduction }\end{array}$ \\
\hline
\end{tabular}


The advantages (McKenna, 1995, p.147) of an ethics theory based on rights are that it:

- preserves the basic values that have become embedded in our moral beliefs: freedom, equality of opportunity, and concern for the disadvantaged;

- fits the basic economic institutions of Western societies;

- incorporates both the communitarian and individualistic strains that are intertwined in Western culture;

- takes into account the criteria of need, ability, effort and contribution;

\section{Table 4. Example of a Stakeholder Analysis}

From a business ethics viewpoint:

- Self-interest is tempered not by the invisible hand of the market place but by individual concern for the disadvantaged

- Communitarian/societal ethics provide a rationale for the protection of the environment for future generations.

Criticisms of the rights theory are that it does not tell us how to determine equality or proportions and therefore lacks substance as a specific guide for conduct. Further, actioning Rawls' second principle would require requires that

- individuals Co-operate in the transfer of holdings to the disadvantaged;

- each person should have access to the training and education needed to perform the desirable jobs, so that efforts and abilities would determine the allocation of positions and rewards.

Ethical reasoning in a stakeholder analysis means asking:

- What is equitable, just, fair and good for those who affect and are affected by business decisions?

- Who are the weaker stakeholders in terms of power and influence?

- Who can, who will, and who should help weaker stakeholders make their voices heard and encourage their participation in the decisional process and outcomes?

- How does a corporation define and fulfil their ethical obligations to affected constituencies?

\section{Ethical reasoning Tools for managing an ethical response to ESG}

Tools for managing ethical decision making include:

- Issues management: anticipating the issues via environmental scanning

- Using stakeholder analysis to assess the impacts; and

- Decision making model

Issues management, often the first step in strategic management, requires: 


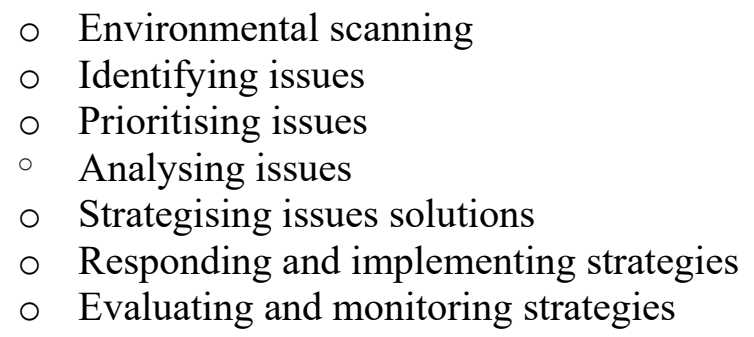

An example of a stakeholder analysis can be seen in Table 3. A stakeholder analysis identifies the stakeholders, their role in the issue and their interests, values, needs and expectations. Among the difficulties of stakeholder analysis is the difficulty of identifying their interests, etc. The advantage is that it lays bare conflicting interests, power blocks and potential supporters.

\section{Decision Making Model}

There are several decision making models available. The following classic approach has a number of steps:

- Step 1: Identify the decision. You realize that you need to make a decision. ...

- Step 2: Gather relevant information. ...

- Step 3: Identify the alternatives. ...

- Step 4: Weigh the evidence. ...

- Step 5: Choose among alternatives. ...

- Step 6: Take action. ...

- Step 7: Review your decision \& its consequences.

The difficulties here are getting to the "How" and "why" of the problem and gathering appropriate evidence to clarify the alternatives.

\section{Conclusion}

In the introduction to a review of 190 studies Clark et al $(2015, \mathrm{p} .8)$ stated: "Sustainability is one of the most significant trends in financial markets for decades. Whether in the form of investors' desire for sustainable responsible investing (SRI), or corporate management's focus on corporate social responsibility (CSR), the content, focusing on sustainability and ESG (environmental, social and governance) issues, is the same". The authors concluded that $88 \%$ of the research shows that solid ESG practices result in better operational performance of firms and in $90 \%$ of the studies on the cost of capital, sound sustainability standards lowered the cost of capital of companies.

Case studies of environmental, social and governance programs conducted by Bonini et al. (2009) also provided support for benefits accruing from growth, improved returns on capital, reduced risk and improved quality of management. The findings confirmed a significant positive relationship between broader ESG factors and firm valuations indicated that higher rated companies are associated with higher earnings multiples. By suggesting that ESG factors impact corporate financial performance, they concluded that they are, therefore, relevant for consideration by investment decision-makers. 
Horrigan (2010) asserted that the primary asset of multinational corporations is now their reputation, which can be lost in an instant with one globally communicated bad news story. In contrast, a company's reputation is enhanced by ESG programs that meet the needs of the community, and especially those that go beyond regulatory requirements and industry norms.

This Paper added to understanding of the meaning of ethics and its relationship to ESG. The ethical theories provide a rationale, ideas and vocabulary to help participate effectively in ethical decision making that can address ESG issues. The ethical reasoning tools support a pragmatic, even defensive, resolution of the conflicts between economic and other objectives that can recognise human needs, rights and justice. Corporate survival in modern society requires awareness that ethical decision making is an indispensable part of business strategy. Overall, this paper provides the ethical theories and models for our corporate leaders to manage corporate responses to ESG. 
Armstrong | Ethics and ESG

\section{References}

Bonini, S. Koller, S. Mirvis, P.H. (2009). Valuing Social Responsibility Programs. McKinsey Quarterly 32(2):11-18

Buchholz, R.A. (1995). Business Environment and Public Policy. Englewood Cliffs, Prentice Hall.

Cadbury, A. (1992). Report on the Committee on the Financial Aspects of Corporate Governance. London, Gee.

Clarke, G.L., Feiner, A,. \& Viehs, M., (2015). From the Stockholder to the Stakeholder: How Sustainability can drive financial out performance, University of Oxford Press. https://doi.org/10.2139/ssrn.2508281

Global Reporting Initiative. (GRI) (2013b). G4 Sustainability Reporting Guidelines: Reporting Principles and Standard Disclosures. Amsterdam: Global Reporting Initiative.

Heenetigala, K., De Silva Lokuwaduge, C., Armstrong, A., \& Ediriweera, A. (2016). Investigation of criteria used for assurance practices of sustainability reporting in Australian listed companies. Melbourne: Victoria University.

Horrigan, B. (2010) Corporate Social Responsibility in the 21st Century: Debates, Models, and Practices Across Government, Law, and Business. Edward Elgar, UK.

IFAC (2012). Investor Demand for Environmental, Social, and Governance Disclosures: Implications for Professional Accountants in Business. New York, International Federation of Accountants.

United Nations (2015). Transforming our world: the 2030 Agenda for Sustainable Development. Accessed 5 December 2019. https://sustainabledevelopment.un.org/post2015/transformingourworld 